\title{
Cryoconservation of Oocytes in a Patient with Breast Cancer and Intrauterine Early Pregnancy
}

\author{
Kryokonservierung von Eizellen bei Mammakarzinom \\ und gleichzeitig bestehender intrauteriner Frühschwangerschaft
}

Authors

Affiliation
M. Werling, A. Tandler-Schneider, A. Siemann, G. Stief, H. Kentenich

Fertility Centre Berlin, Berlin

\section{Key words}

- Cryoconservation of oocytes

- early pregnancy

- breast cancer

- midluteal protocol

- aromatase inhibitor

Schlüsselwörter

- Kryokonservierung von Eizellen

- Frühschwangerschaft

- Mammakarzinom

- mittluteales Protokoll

- Aromataseinhibitor

\section{received $\quad 10.4 .2012$ \\ revised $\quad 6.6 .2012$ \\ accepted $\quad 9.7 .2012$}

Bibliography

Dol http://dx.doi.org/

10.1055/s-0032-1315244

Geburtsh Frauenheilk 2012; 72:

1029-1032 @ Georg Thieme

Verlag KG Stuttgart · New York .

ISSN 0016-5751

\section{Correspondence}

Dr. Marina Werling

Fertility Centre Berlin

Spandauer Damm 130

14050 Berlin

werling@fertilitycenterberlin.de

\section{Abstract}

$\nabla$

Case Report: A 38-year-old patient newly diagnosed with invasive ductal breast cancer wished to cryoconserve her unfertilised oocytes. Stimulation was started on the 26th day of her menstrual cycle with daily administration of 300 IE hMG s.c. and a GnRH antagonist (cetrorelix $0.25 \mathrm{mg}$ s.c.). The patient additionally received an aromatase inhibitor during the first 5 days of stimulation (letrozole $5 \mathrm{mg}$ p.o.). Induction of ovulation occurred on the 11th day of stimulation with hCG (10000 IE s.c.) and a GnRH agonist (triptorelin $0.2 \mathrm{mg}$ s.c.). Seventeen oocytes were retrieved during follicle puncture and 11 were cryopreserved. Despite the administration of cetrotide (a $\mathrm{GnRH}$ antagonist) no luteolysis occurred during stimulation. A pregnancy test was therefore done on the 11th day of stimulation and the result was positive ( $\beta$-HCG $3493 \mathrm{mIU} / \mathrm{ml}$ ). Sonography showed an intrauterine pregnancy. The patient was in gestational week $5+0$. The aspirated oocytes mostly showed a normal morphology (metaphase II) despite high progesterone levels during stimulation. The patient decided to terminate the pregnancy before starting adjuvant chemotherapy.

Conclusion: We describe the case of a patient who underwent stimulation for cryopreservation of oocytes during a spontaneous pregnancy conceived in the same cycle just before starting stimulation. Stimulation was done over a short period using a combination of a GnRH antagonist and an aromatase inhibitor to ensure the lowest possible estradiol levels. The quality of the oocytes does not appear to have been negatively affected by the high progesterone levels of early pregnancy.

\section{Zusammenfassung \\ V}

Kasuistik: Eine 38-jährige Patientin wünschte nach Erstdiagnose eines invasiv duktalen Mammakarzinoms eine Kryokonservierung unbefruchteter Eizellen. Die Stimulation wurde am 26. Zyklustag begonnen mit täglich $300 \mathrm{IE}$ hMG s.c. und einem GnRH-Antagonisten (Cetrorelix $0,25 \mathrm{mg}$ s.c.). Zusätzlich wurde während der ersten 5 Stimulationstage ein Aromatasehemmer (Letrozol $5 \mathrm{mg}$ p.o.) appliziert. Die Ovulationsinduktion erfolgte am 11. Stimulationstag mit HCG (10000 IE s.c.) und einem GnRH-Agonisten (Triptorelin 0,2 mg s.c.). Bei der Punktion wurden 17 Oozyten gewonnen und 11 kryokonserviert. Während der Stimulation setzte trotz Cetrotide (GnRH-Antagonist) keine Luteolyse ein, sodass am 11. Stimulationstag ein Schwangerschaftstest durchgeführt wurde. Dieser zeigte einen positiven Wert ( $\beta$-HCG 3493 mIU/ml). Zeitgleich wurde intrauterin eine Fruchthöhle sichtbar. Die Patientin befand sich zu dem Zeitpunkt in der 5 + 0 SSW p. m. Morphologisch handelte es sich trotz der hohen Progesteronwerte während der Stimulation größtenteils um normal reife Eizellen (Metaphase II). Die Patientin entschloss sich vor Beginn der adjuvanten Chemotherapie zur Abruptio.

Zusammenfassung: Diese Kasuistik zeigt eine Stimulation mit Kryokonservierung von Eizellen bei einer im gleichen Zyklus unmittelbar vor Beginn der Stimulation spontan entstandenen intrauterinen Schwangerschaft. Die Stimulation wurde innerhalb kurzer Zeit in Kombination mit GnRHAntagonisten und einem Aromatasehemmer zur Gewährleistung möglichst niedriger Östrogenspiegel durchgeführt. Die Qualität der Eizellen scheint durch die hohen Progesteronwerte in der Frühschwangerschaft nicht negativ beeinflusst. 


\section{Introduction}

As the survival rates of younger patients with oncological disease have continued to improve, there has been an increased awareness of the importance of maintaining fertility and fulfilling the wish of patients to have children. Preservation of fertility is particularly suitable for women with breast cancer, as hysterectomy is an essential part of surgical therapy to treat cervical, uterine corpus and ovarian cancer - except in younger patients with early stage disease and the wish to conceive. Around 5\% of women carry a pregnancy to term after breast cancer. To what extent cytostatic therapy induces amenorrhea largely depends on patient age ( $<>40$ years) and the cumulative dosage of cyclophosphamides [1].

There are a number of options available to protect fertility prior to starting chemotherapy: one option consists of ovarian stimulation with cryoconservation of fertilised or unfertilised oocytes. As it is highly effective and IVF and ICSI are extremely well researched technologies, this method is the option advocated by the fertility preservation network FertiPROTEKT. A number of different protocols can be used for stimulation.

Another option consists of cryoconserving ovarian tissue after laparoscopic removal. However, experience with this technique is very limited and only a few children have been born after retransplantation [2]. The risk of metastasis after re-transplantation cannot be entirely excluded, even if there are as yet no reports of metastasis in humans after re-transplantation. In vitro maturation allows immature oocytes to be retrieved without or with only limited stimulation and the oocytes are then cultured to maturation prior to being cryopreserved. However, the reported fertility and pregnancy rates to date are distinctly lower. GnRH analogues can have a protective effect during chemotherapy [3]. However, it is possible that GnRH analogues may reduce the impact of chemotherapy due to reduced tumour cell growth in hormone-dependent carcinomas. Outside clinical studies, the administration of a $\mathrm{GnRH}$ analogue for ovarian protection together with chemotherapy should only be done after discussing the option with patients with hormone receptor-negative tumours $[4,5]$.

\section{Case Report}

$\nabla$

A 38-year-old gravida 1l, para 0 was advised on fertility preservation after being newly diagnosed with invasive ductal breast cancer. The patient's previous history included 1 miscarriage, 1 termination and adnexitis. The patient reported that her cycles were regular (29-30/4) and that until the diagnosis of breast cancer she had used Cerazette ${ }^{\circledR}$ for contraception. The first meeting with the patient took place after mastectomy for invasive ductal breast carcinoma, stage pT2, pN2 (6/12), G2, L1, R0, M0, ER 10/12, PR 10/ 12, Her2neu 1+. Adjuvant chemotherapy was planned to start within two weeks.

The patient's hormonal status on the 13th day of her menstrual cycle showed normal gonadotropin levels, and she was normoandrogenaemic and euthyreotic. Anti-Müllerian hormone levels were $4.04 \mathrm{ng} / \mathrm{ml}$ (normal range: $1.0-2.5 \mathrm{ng} / \mathrm{ml}$ ), indicating a good ovarian reserve. The patient was informed in detail about all options for fertility preservation (cryoconservation of fertilised/ unfertilised oocytes, ovarian tissue banking, in vitro maturation, GnRH analogues). Because IVF/ICSI has been tested over many years and currently has the best prognosis for a successful future pregnancy, the patient opted for cryoconservation of oocytes. As the patient was not in a long-term relationship the plan was to cryoconserve unfertilised oocytes. As there was only a very short interval before starting chemotherapy, stimulation was started in the second half of the cycle on the 26th day of the patient's cycle. The patient received 300 IE hMG s.c. daily and a GnRH antagonist (cetrorelix $0.25 \mathrm{mg}$ s.c.) as well as an aromatase inhibitor (letrozole $5 \mathrm{mg}$ p.o.) during the first 5 days of stimulation. Ovulation was induced on the 11th day of stimulation using hCG (10000 IE s.c.) and a $\mathrm{GnRH}$ agonist (triptorelin $0.2 \mathrm{mg}$ s.c.) ( $\bullet$ Table 1 ). Surprisingly, no luteolysis occurred during stimulation despite the administration of a GnRH antagonist, and a pregnancy test was done on the 11th day of stimulation. The test was positive ( $\beta$-hCG 3493 mIU/ml, E 1848 pg/ml, prog 19 ng/ml). Sonography showed an intrauterine pregnancy. It was calculated that the patient was in gestational week $5+0$.

Oocyte retrieval was done on the 13th day of stimulation. Seventeen oocytes were aspirated. Most of the aspirated oocytes had a

Table 1 Stimulation chart.

\begin{tabular}{|c|c|c|c|c|c|c|c|c|c|c|c|c|c|}
\hline Day of stimulation & 1 & 2 & 3 & 4 & 5 & 6 & 7 & 8 & 9 & 10 & 11 & 12 & 13 \\
\hline Letrozole (5 mg) & $\checkmark$ & $\checkmark$ & $\checkmark$ & $\checkmark$ & $\checkmark$ & & & & & & & & \\
\hline hMG (IE) & 300 & 300 & 300 & 300 & 300 & 300 & 300 & 300 & 300 & 300 & & & \\
\hline Cetrorelix (Amp.) & 1 & 1 & 1 & 1 & 1 & 1 & 1 & 1 & 1 & 1 & 1 & & \\
\hline Predalone (IE) & & & & & & & & & & & 10000 & & \\
\hline Triptorelin (mg) & & & & & & & & & & & 0.2 & & \\
\hline $\mathrm{E} 2(\mathrm{pg} / \mathrm{ml})$ & & & & & & 88 & & 543 & & & 1848 & & \\
\hline LH (IU/I) & & & & & & 0.72 & & 1.3 & & & 3.8 & & \\
\hline PGN (ng/ml) & & & & & & 16 & & 13 & & & 19 & & \\
\hline$\beta$-HCG & & & & & & & & & & & 3493 & & \\
\hline Sonography & & & & & & $3 \times 8$ & & 14 & & & 23 & & \\
\hline \multirow[t]{4}{*}{ right ovary } & & & & & & & & $4 \times 8$ & & & 21 & & \\
\hline & & & & & & & & & & & 19 & & \\
\hline & & & & & & & & & & & 18 & & \\
\hline & & & & & & & & & & & $2 \times 16$ & & \\
\hline Sonography & & & & & & $3 \times 8$ & & $2 \times 14$ & & & 18 & & \\
\hline \multirow[t]{2}{*}{ left ovary } & & & & & & & & $4 \times 6$ & & & 17 & & \\
\hline & & & & & & & & & & & $3 \times 14$ & & \\
\hline Endometrium & 8 & & & & & 8 & & 8 & & & 9 & & \\
\hline
\end{tabular}


normal morphology, and the majority were metaphase II (11 $x$ MII; $2 \times \mathrm{MI} ; 4 \times \mathrm{GV}$ ). Cryoconservation was done using Borini's slow freezing method [6]. Treatment was carried out with the help of the FertiPROTECT network. The patient took the decision to terminate the pregnancy after intensive discussions with the oncologist. Adjuvant chemotherapy $(3 \times$ FEC, $3 \times$ paclitaxel $)$ was then started as planned.

\section{Discussion}

$\nabla$

Various protocols can be used for ovarian stimulation with subsequent cryoconservation of fertilised or unfertilised oocytes. Usually a conventional antagonist protocol is used, with gonadotropin stimulation started on the 2nd day of the cycle. In this case hMG was used for stimulation at the patient's request to reduce costs. A GnRH antagonist is administered from the 6th day of stimulation onwards to prevent early ovulation. Modified stimulation protocols have been developed specifically for oncological patients so that chemotherapy can be started within 14 days. With these protocols stimulation can be initiated in every phase of the cycle using recombinant follicle stimulating hormone (FSH) with simultaneous administration of an antagonist from the start of stimulation $[4,5,7]$. Onset of luteolysis is important for successful stimulation in the 2nd half of the menstrual cycle. The goal of stimulation is maturation and retrieval of oocytes, as endometrium transformation in preparation for pregnancy is not required. In this case there was the additional goal of maintaining relatively low estradiol levels to minimise any potentially negative impact on the hormone receptor-positive breast carcinoma. The combination of gonadotropins with an aromatase inhibitor allows estradiol levels to be maintained at or just over the levels present in the natural menstrual cycle [8]. No increased risk of recurrence has been reported to date [9].

There is only limited data on the safety of ovarian stimulation in patients with receptor-positive breast cancer, and a careful riskbenefit analysis in close consultation with the patient and the oncologist is necessary. Theoretically, higher estradiol levels could trigger increased tumour cell growth. However, it is questionable whether a short-term elevation of estradiol levels will actually result in a relevant worsening of prognosis. Moreover, it is important to bear in mind that even without stimulation patients can have relatively high endogenous estradiol levels prior to chemotherapy (300-400 pg/ml estradiol in the middle of the cycle). No negative effect on prognosis was found in a study of 91 patients with localised disease $[5,6,10]$.

We describe here an unusual case of a pregnancy conceived spontaneously within the same cycle immediately prior to the start of stimulation in the second half of the cycle. Apart from the problem of an early pregnancy and the urgent necessity of adjuvant chemotherapy another factor also had to be discussed with the patient: the 5-day administration of an aromatase inhibitor in early pregnancy meant that it was not possible to exclude potential teratogenic effects on the foetus. An adverse effect of gonadotropin stimulation and administration of a GnRH antagonist on the pregnancy is probably negligible. Administration of an aromatase inhibitor is commonly done over the entire course of stimulation until the induction of ovulation. We deviated from this protocol in our case because non-onset of luteolysis indicated a possible early pregnancy.

We decided in favour of a combination of hCG (10000 IE) and a GnRH agonist (triptorelin $0.2 \mathrm{mg}$ ) to induce ovulation. We con- sidered that the standard use of hCG, which induces ovulation through binding to the LH receptor, was not appropriate as the patient was already producing hCG due to her pregnancy. As there are no reports in the literature on the induction of ovulation in pregnancy, we opted for this "safe" combination of both preparations.

There was also a risk that the oocytes would not be able to reach metaphase II or that they had already reached the stage due to endogenous production of hCG and might have become atretic. Due to the continuous high progesterone levels we initially had to assume that oocyte maturation might be impaired. Surprisingly, morphological examination of the oocytes did not confirm this.

It should be noted critically that a pregnancy test could have been done a few days earlier. Moreover, after discussing it with the patient, it would have been possible to administer the aromatase inhibitor for a longer period to ensure an optimal decrease of estradiol levels as the concerns about teratogenicity are probably speculative.

\section{Conclusion \\ $\nabla$}

We report an unusual case of spontaneous pregnancy conceived shortly before the start of stimulation in the 2nd half of the menstrual cycle. Stimulation was done in the shortest possible time, starting in the 2nd half of the cycle with gonadotropins and $\mathrm{GnRH}$ antagonists in combination with an aromatase inhibitor to ensure relatively low estradiol levels. Surprisingly, morphological examination of the oocytes showed no impairment due to the pregnancy. We cannot draw any definitive conclusions about the future potential of the oocytes to be fertilised.

There is not sufficient data about the risk of ovarian stimulation in patients with receptor-positive breast cancer. Treatment should be done in centres integrated in the FertiPROTEKT network.

\section{Conflict of Interest}

$\nabla$

None.

\section{References}

1 Stearns V, Schneider B, Henry NL et al. Breast cancer treatment and ovarian failure: risk factors and emerging genetic determinants. Nat Rev Cancer 2006; 6: 886-893

2 von Wolff M, Donnez J, Hovatta $O$ et al. Cryopreservation and autotransplantation of human ovarian tissue prior to cytotoxic therapy - a technique in its infancy but already successful in fertility preservation. Eur J Cancer 2009; 45: 1547-1553

3 Blumenfeld Z, von Wolff $M$. GnRH-analogues and oral contraceptives for fertility preservation in women during chemotherapy. Hum Reprod Update 2008; 14: 543-552

4 von Wolff M, Montag M, Dittrich R et al. Fertility preservation in women - a practical guide to preservation techniques and therapeutic strategies in breast cancer, Hodgkin's Iymphoma and borderline ovarian tumors by the fertility preservation network FertiPROTEKT. Arch Gynecol Obstet 2011; 284: 427-435

5 von Wolff M, Montag M, Dittrich R et al. Fertilitätsprotektion bei Frauen - Empfehlungen des Netzwerkes FertiPROTEKT. Geburtsh Frauenheilk 2010; 70: R83-R100

6 Borini A. Clinical outcome of oocyte cryopreservation after slow cooling with a protocol utilizing a high sucrose content. Hum Reprod 2006; 21: 512-517 
7 von Wolff M, Thaler CJ, Frambach $T$ et al. Ovarian stimulation to cryopreserve fertilized oocytes in cancer patients can be started in the luteal phase. Fertil Steril 2009; $92: 1360-1365$

8 Oktay K, Hourvitz A, Sahin G et al. Letrozole reduces estrogen and gonadotropin exposure in women with breast cancer undergoing ovarian stimulation before chemotherapy. J Clin Endocrinol Metab 2006; 91: 3885-3890
9 Azim AA, Constantin-Ferrando M, Oktay K. Safety of fertility preservation by ovarian stimulation with letrozole and gonadotropins in patients with breast cancer: a prospective controlled study. J Clin Oncol 2008; 26: 2630-2635

10 Sankila R, Heinävaara S, Hakulinen T. Survival of breast cancer patients after subsequent term pregnancy: healthy mother effect. AM J Obstet Gynecol 1994; 170: 818-823

Deutschsprachige Zusatzinformationen online abrufbar unter: www.thieme-connect.de/ejournals/toc/gebfra. 